Available online at website :

http://e-journal.adpgmiindonesia.com/index.php/jmie

JMIE: Journal of Madrasah Ibtidaiyah Education, 4(1), 2020, 53-67

\title{
PENGARUH METODE DRILL PENCAK SILAT TERHADAP KECERDASAN KINESTETIK SISWA SEKOLAH DASAR
}

\author{
Fery Muhamad Firdaus'), Prayogi Nurfauzan'2), Rianti Hanaris ${ }^{3)}$ \\ Universitas Negeri Yogyakarta ${ }^{1)}$, Universitas Islam 45 Bekasi (Unisma Bekasi)2) \\ Sekolah Tinggi Keguruan dan Ilmu Pendidikan (STKIP) Subang3)
}

Email: fery.firdaus@uny.ac.id ${ }^{1)}$,prayoginurfauzan99@yahoo.com²), riantihanarisa123@gmail.com³)

Naskah diterima : 7 Januari 2020, direvisi : 29 April 2020, disetujui : 30 April 2020

\begin{abstract}
This research tries to study effective and significant pencak silat drill methods and affects hearing on the kinesthetic intelligence of third grade students at Sri Asih State Elementary School. The study was conducted using quantitative, as well as quasi-experimental methods. Hypothesis test results indicate the average value of kinetic intelligence scores of elementary school students who use the pencak silat drill method that is 74.04 , the standard deviation is 40.0778 and the standard error is 7.5740. Meanwhile, for the second output showing the results of the $\mathrm{t}$ test for the test value $=50$, the $\mathrm{t}$-count $=-504,027$ and the sig 2 -tailed value $=0.120$. A 2 -tailed sig value $=120$ multiplied by $1 / 2$ and a P-value $=1 / 2 \times 0.120=0.060$ is obtained. Because the P-value is $>1 / 2 \alpha, \mathrm{H} 0$ is accepted. In addition, observations showed that 10 out of 14 children met the kinesthetic intelligence indicator, while the other 4 each only met the two indicators that were tested. So, it can be concluded that the pencak drill method determines significantly the kinesthetic intelligence of elementary school students.
\end{abstract}

Keywords: Pencak silat drill method, kinesthetic intelligence.

Pengutipan: Firdaus, Fery Muhamad, dkk. (2020). Pengaruh Metode Drill Pencak Silat Terhadap Kecerdasan Kinestetik Siswa Sekolah Dasar. JMIE: Journal of Madrasah Ibtidaiyah Education,4(1), 53-67. jmie.v4i1.171. 


\section{PENDAHULUAN}

Pendidikan merupakan hal yang sangatlah diperlukan manusia untuk melaksanakan fungsi-fungsi kehidupan. Somarya dan Nuryani (Rasyidin dkk, 2016: 26) mengungkapkan bahwa pendidikan berfungsi untuk meningkatkan kualitas daya manusia baik sebagai individu maupun kelompok. Tentunya Pendidikan juga berfungsi untuk meningkatkan potensi jasmani, rohani, spiritual, material serta kematangan berpikir manusia sebagai upaya untuk meningkatkan sumber daya manusia.

Di dalam Undang-undang Sistem Pendidikan Nasional No. 20 Tahun 2003 disebutkan bahwa pendidikan adalah usaha sadar dan berancana untuk mewujudkan suasana belajar dan proses pembelajaran agar peserta didik secara aktif mengembangkan potensi dirinya untuk memiliki kekuatan spiritual keagamaan, pengendalian diri, kepribadian, kecerdasan, akhak mulia, serta keterampilan yang diperlukan dirinya, masyarakat, bangsa dan negara.

Menoleh dari beberapa pentingnya pendidikan untuk menunjang keberlangsungan suatu bangsa melalui jalan mempersiapkan peserta didik sebagai pondasi utama berdirinya suatu negara yang kokoh maka diperlukan peserta didik yang aktif. Penelitian Alfano (Mulyasari, 2014 : 374) menunjukkan bahwa gerakan merupakan elemen yang penting dalam melaksanakan belajar melalui permainan, hal ini dikarenakan gerakan berasal dari otak anak sehingga aktivitas fisik sangatlah diperlukan dalam pembelajaran. Siswa yang sering melakukan aktivitas gerakan, maka akan mampu mengembangkan keterampilan yang akan dibutuhkan dalam kehidupan seharai-hari. Serta aktivitas fisik merupakan hala yang sangat penting dalam merangsang kemampuan mental siswa.

Kecerdasan fisik sangat mempengaruhi perkembangan motorik anak. Menurut Sumantri (Mulyasari, 2014 : 374) Perkembangan motorik merupakan proses yang berkesinambungan dan sejalan dengan perkembangan usia manusia secara bertahap, dari mulai gerakan yang sederhana, gerakan yang tidak terorganisasi, gerakan yang tidak terampil kearah penampilan keterampilan motorik yang kompleks dan terorganisasi dengan baik. Hal tersebut akan menuju pada kearah penyesuaian keterampilan menyertai terjadinya proses menua (menjadi tua).

Namun di era globalisasi seperti sekarang ini pesatnya perkembangan teknologi mempengaruhi kegiatan anak dalam menggerakkan seluruh anggota tubuhnya. Siswa sekolah dasar cenderung banyak menghabiskan waktu menggunakan gadget yang tidak terlalu banyak melakukan aktivitas fisik. Mereka pun bisa menghabiskan waktu berjam-jam hanya untuk berseluncur di sosial media yang mereka punya. Pada akhirnya siswa yang terlalu banyak memainkan gadget akan menjadi kecanduan dan cenderung malas untuk melakukan aktivitas fisik. Sehingga akan mempengaruhi Kesehatan jasmani siswa tersebut.

Menurut survei yang dilakukan oleh YPMA (Yayasan Pengembangan Media Anak) tahun 2006 menemukan bahwa anak menghabiskan 7 jam sehari untuk mengkonsumsi media, 
mulai dari televisi, komputer, video game, dan sebagainya. Diperkuat oleh data yang menyebutkan bahwa anak biasanya bermain game setelah pulang sekolah. Yang mengejutkan, sejumlah responden (3\%) mengaku bermain game sampai larut malam, di atas pukul 10 malam (Cahyaningrum, 2015 : 5). Hal tersebut tentunya akan mempengaruhi aktivitas fisik yang rendah pada anak, sehingga anak tidak akan mampu mengembangkan kecerdasan kinestetik, padahal kecerdasan kinestetik ini sangatlah dipelukan dalam pengembangan potensi anak suapaya dapat tumbuh menjadi pribadi dewasa yang sehat dan terampil dalam menyelesaikan masalah di kehidupan sehari-hari. Oleh karena itu, guru seyogyanya merancang dan mengimplementasikan model-model atau strategi pembelajaran yang menarik motivasi siswa dalam melakukan berbagai aktivitas fisik Ketika pembelajaran berlangsung.

Bila berbicara mengenai lingkup pendidikan formal, kurangnya pembelajaran yang aktif dan interaktif menjadi salah satu masalah yang hendak diselesaikan oleh para praktisi pendidikan, terutama guru sebagai pelaksana pembelajaran pada satuan pendidikan. Anak-anak kurang mendapat rangsangan untuk melakukan sesutu berdasarkan dengan apa yang mereka pikirkan. Terkadang orang-orang di sekitar anak pun menjadi pemicu anak kurang mengekpresikan ide-ide mereka lewat tindakan karena takut disebut anak nakal. Jika hal seperti ini terus dibiarkan kesempatan siswa untuk mengembangkan potensi dirinya jadi menyempit. Bibit-bibit untuk menjadi penari, olahragawan, dan lain sebagainya akan terhalangi.

Berdasarkan hasil studi pendahuluan pada siswa kelas III SDN Sri Asih, peneliti menemukan masalah kurangnya kecerdasan kinestetik siswa yang ditandai dengan masih terdapatnya siswa yang kurang memiliki kemampuan koordinasi dalam melakukan aktifitas fisik, keseimbangan gerak anggota tubuh, keterampilan-keterampilan kinestetik, kekuatan ketahanan tubuh, kelenturan tubuh, dan kecepatan serta kemampuan menerima rangsangan (proprioceptive) dan beberapa hal yang berhubungan dengan sentuhan (tactile dan haptic). Padahal kecerdasan kinestetik siswa sangatlah penting dikembangkan di usia dini, karena secara karakteristiknya pun mereka masih memerlukan keterampilan fisik dalam pembelajaran. Seperti yang dikemukakan oleh Gardner (Campbell dkk. 2005: 2-3) bahwa melalui kinesthetic intelligence (kecerdasan kinestetik), seseorang dapat menggerakkan anggota tubuh ataupun objek dalam melakukan aktivitas fisik supaya mereka mampu mengembangkan keterampilanketerampilan fisik yang halus. Selain itu, Amstrong (2013) juga berpendapat bahwa kecerdasan kinestetik atau kecerdasan fisik merupakan suatu kecerdasan seseorang dalam menggunakan berbagai anggota tubuh yang dimiliki untuk melakukan gerakan-gerakan fisik seperti berjalan, berlari, memukul, menendang, menari, dan aktivitas-aktivitas lain yang menggunakan anggota tubuh manusia. Kecerdasan kinestetik ini sangatlah mempengaruhi terhadap perkembangan motorik anak, sehingga sangatlah perlu manakala dikembangkan dalam pembelajaran.

Menurut Musfiroh, (Suhaimi, 2017), kecerdasan kinestetik merupakan kemampuan seseorang mengontrol dan mengolah gerakan-gerakan yang menggunakan anggota tubuh 
secara baik. Anak yang memiliki kecerdasan kinestetik yang tinggi biasanya akan menguasai secara cepat berbagai aktivitas yang melibatkan fisik mereka, seperti gerakan motorik, baik motorik kasar amaupun motorik halus. Selain itu, anak yang memiliki kecerdasan kinestetik tinggi akan mampu mengekspresikan berbagai ide atau gagasan yang dimilikinya melalui gerak tubuh. Peristiwa ini dapat sering kita jumpai di lembaga pendidikan anak usia dini maupun sekolah dasar. Kecerdasan kinestetik juga berkaitan dengan kemampuan siswa untuk mengungkap perasaan yang mereka rasakan melalui gerakan-gerakan anggota tubuh, serta mereka akan terampil menciptakan suatu karya melalui tangan atau anggota tubuh mereka lainnya.

Pentingnya kecerdasan kinestetik siswa ini sangat mendorong peneliti untuk mengatasi masalah rendahnya kecerdasan kinestetik siswa kelas III SDN Sri Asih. Untuk itu, peneliti mempertimbangkan berbagai alternatif penyelesaian masalah yang dapat digunakan pada penelitian ini. Alternatif pemecahan masalah yang akan dilaksanakan tentunya mempertimbangkan dari hasil-hasil penelitian terdahulu mengenai kecerdasan kinestetik siswa. Seperti hasil penelitian yang sudah ditemukan oleh Indriati, dkk (2014) yang menunjukkan bahwa kecerdasan kinestetik siswa dapat ditingkatkan melalui penerapan metode drill pada pembelajaran tari kreasi di Taman Kanak-Kanak Mekar Indah Kota Bengkulu. Selain itu, hasil penelitian Dodong Wiganda (2019) juga menunjukkan bahwa kecerdasan kinestetik dapat ditingkatkan melalui metode bermain pada pembelajaran pendidikan jasmani olahraga dan kesehatan di Sekolah Dasar Negeri (SDN) Nangela Kabupaten Bandung.

Berdasarkan pemaparan di atas, peneliti tertarik untuk melakukan penelitian secara teoritik dan praktik untuk melihat pengaruh yang dapat ditimbulkan dari metode drill pencak silat terhadap kecerdasan kinestetik siswa kelas III SDN Sri Asih. Metode drill dipilih berdasarkan hasil penelitian Indriati, dkk (2014) yang akan diujicobakan pada pembelajaran pencak silat di sekolah dasar senada dengan hasil penelitian yang telah dilaksanakan Dodong Wiganda (2019).

Metode drill merupakan suatu kegiatan yang dilakukan secara berulang, serta bersungguh-sungguh untuk mencapai tujuan pembelajaran yang diharapkan. Aktivitas yang berulang ini dilakukan untuk menyempurnakan suatu keterampilan agar dimiliki siswa secara permanen. Yang menjadi ciri khas dari metode drill ini yaitu kegiatan berupa pengulangan yang dilakukan secara berkali-kali dari suatu hal yang sama (Sudjana, 2013: 18). Sedangkan Djamarah dan Zain (2010) menjelaskan bahwa metode drill merupakan suatu cara mengajar yang baik untuk menanamkan kebiasaan-kebiasaan tertentu.

Pencak silat merupakan salah satu hasil karya seni budaya asli Indonesia yang sudah turun temurun dari nenek moyang yang masih melekat pada masyarakat sampai sekarang. Para pakar pencak silat meyakini bahwa masyarakat Melayu lah yang telah menciptakan budaya pencak silat dan menggunakan ilmu bela diri sejak masa prasejarah. Hal ini dikarenakan pencak 
silat menjadi kebutuhan masyarakat prasejarah untuk dapat melawan binatan buas yang liar melalui gerakan-gerakan bela diri atau bela serang. Manusia zaman prasejarah dituntut untuk survive dalam menjalani kehidupan alam yang keras. Seiring berjalannya waktu, kini pencak silat merupakan kesatuan dari empat aspek yaitu sebagai aspek spiritual, seni budaya, bela diri dan olahraga yang dibutuhkan oleh masyarakat Indonesia. Pencak memiliki arti gerak dasar dalam bela diri yang terikat pada suatu peraturan dalam belajar, berlatih dan pertunjukkan. Sedangkan silat, mempunyai arti suatu gerak bela diri yang bersumber pada kerohanian murni, guna keselamatan diri dan kesejahteraan bersama dalam suatu sistem kehidupan bermasyarakat (Yarmani dan Sutisyana. $2017: 102$ ).

Pencak silat merupakan budaya bangsa Indonesia yang mengandung nilai-nilai luhur jati diri Indonesia yaitu: (1) Budaya Indonesia sebagai asal coraknya, (2) falsafah budi pekerti luhur sebagai jiwa dan sumber motivasi penggunaannya, (3) pembinaan mental spiritual/budi pekerti, beladiri, seni, olahraga sebagai aspek integral dari substansinya. Pencak silat yang dihayati keseluruh nilainya akan mempunyai manfaat yang besar bagi individu yang mempelajarinya, serta bagi masyarakat pada umumnya (Sukarna, dkk, 2015). Oleh karena itu, pencak silat berkontribusi dalam kemajuan pendidikan Indonesia, sehingga perlu kiranya pencak silat ini dilatih dan dikembangkan untuk anak usia dini dan sekolah dasar supaya kecerdasan kinestetik mereka dapat berkembang secara baik dan sebagaimana mestinya.

Berdasarkan paparan permasalahan mengenai rendahnya kecerdasan kinestetik siswa Sekolah dasar, maka peneliti merumuskan pertanyaan penelitian yaitu: "apakah terdapat pengaruh metode drill pencak silat terhadap kecerdasan kinestetik siswa kelas III SDN Sri Asih?”. Sehingga penelitian ini bertujuan untuk menemukan pengaruh metode drill pencak silat terhadap kecerdasan kinestetik siswa kelas III SDN Sri Asih.

\section{METODE}

Penelitian ini dilaksanan di kelas III tahun ajaran 2018/2019 Sekolah Dasar Negeri Sri Asih Kmp. Bakan Sawah RT 16/07 Desa Cidahu Kecamatan Pagaden Barat Kabupaten Subang. Penelitian dilaksanakan dengan menggunakan pendekatan kuantitatif, serta metode kuasi eksperimen untuk menemukan pengaruh metode drill terhadap kecerdasan kinestetik siswa sekolah dasar.

Desain eksperiman dalam penelitian ini adalah pre experimental jenis the one-short case study design. One-short case study design ini digunakan dalam penelitian yang terdapat suatu kelompok yang diberi perlakuan (treatment) dan selajutnya diobservasi hasilnya. Perlakuan (treatment) sebagai variabel indevenden dan hasil yang diobservasi sebagai variabel independen (Lestari dan Yudhanegara, $2015:$ 122). 


\section{X $\quad$ O}

Gambar 1. Desain Penelitian The One-Short Case Study Design.

\section{Keterangan :}

$\mathrm{X}=$ perlakuan/treatment yang diberikan (variabel independen)

$\mathrm{O}=$ postes (variabel penden yang diobservasi)

Populasi yang diteliti adalah jumlah kelas III di SD Negeri Sri Asih Kabupaten Subang. Adapun jumlah keseluruhan siswa di SD Negeri Sri Asih adalah 153 siswa. Sampel dalam penelitian ini yaitu siswa-siswi kelas III SD Negeri Sri Asih Kabupaten Subang yang sebanyak 14 siswa.

Dalam melakukan penelitian dibutuhkan persiapan yang matang agar target penelitian bisa tercapai dengan baik. Untuk meminimalisir kesaahan-kesalahan dalam menjalankan penelitian maka dibutuhkan suatu prosedur sebagai pegangan. Adapun tahapan atau langkahlangkah yang dilakukan pada penelitian di SDN Sri Asih ini akan dilaksanakan mengadopsi dari gagasan Lestari dan Yudhanegara (2015 : 223-224) yang dilakukan dengan beberapa tahapan, yaitu: 1) tahap persiapan, 2) tahap penelitian, 3) tahap analisis data yang diperoleh, 4) tahap penarikan kesimpulan. Tahap-tahap tersebut akan diuraikan sebagai berikut :

1. Tahap Persiapan, tahap persiapan diawali dengan melakukan perizinan dalam pelaksanakan penielitian, kemudia melakukan studi pendahuluan, menganalisis masalah, merancang dan membuat instrumen penelitian, mengujicobakan instrumen penelitian, menganalisis hasil uji coba instrumen serta memperbaiki instrumen yang sudah diujicobakan.

2. Tahap Penelitian, tahap pelaksanaan penelitian ini diawali dengan tes awal jika diperlukan, melaksanakan perlakuan (treatment) menggunakan metode drill pencak silat, melakukan pengumpulan data melalui tes praktik kecerdasan kinestetik siswa sekolah dasar, serta observasi kemampuan/kecerdasan kinestetik siswa sekolah dasar.

3. Tahap Analisis Data, tahap analisis data dilakukan dengan cara mengolah data yang diperoleh setelah mengadakan perlakuan (treatment) metode drill pencak silat dan tes kecerdasan kinestetik siswa sekolah dasar. Analisis data ini dilakukan dengan menggunakan teknik statistik tertentu atau dengan mendeskripsikan data yang telah terkumpul sebelumnya, menganalisis data dengan menginterpretasikan hasil pengelolaan data.

4. Tahap Penarikan Kesimpulan, tahap ini dilakukan dengan menarik kesimpulan dari penelitian yang dilakukan dengan cara menjawab berbagai rumusan masalah dalam 
penelitian berdasarkan hasil analisis data dan temuan selama penelitian untuk dapat digeneralisasikan dalam sebuah kesimpulan penelitian.

5. Menyusun Laporan Penelitian, tahap ini dilakukan dengan menyusun laporan penelitian dan mengpublikasikan hasil penelitian dalam jurnal ilmiah.

Teknik yang digunakan oleh peneliti untuk pengumpulan data yaitu teknik pengamatan dan teknik pemberian tes praktek yang diadopsi dari pernyatan Arifin Zainal (2016) untuk mengukur pengaruh metode drill pencak silat terhadap kecerdasan kinestetik siswa sesudah diberikan perlakuan. Adapun teknik pengumpulan data yang dimaksud yaitu:

1) Observasi, observasi pada penelitian ini yaitu suatu proses pengamatan sistematis yang dilakukan peneliti untuk mengamati kemampuan atau kecerdasan kinestetik siswa sekolah dasar dalam melakukan gerakan-gerakan pencak silat saat proses pembelajaran berlangsung.

2) Tes Praktik atau Tes Perbuatan (Performance Test), tes praktik pada penelitian ini yaitu proses tes perbuatan untuk mengukur kecerdasan kinestetik siswa sekolah dasar dilihat dari indikatorindikator kecerdasan kinestetik, yaitu kemampuan koordinasi dalam melakukan aktifitas fisik, keseimbangan gerak anggota tubuh, keterampilan-keterampilan kinestetik, kekuatan ketahanan tubuh, kelenturan tubuh, dan kecepatan serta kemampuan menerima rangsangan (proprioceptive) dan beberapa hal yang berhubungan dengan sentuhan (tactile dan haptic).

Teknik analisis data pada penelitian ini dilakukan dengan cara menguji normalitas, menguji homogenitas, dan menguji hipotesis dengan menggunakan pengujian statistik.

\section{HASIL DAN PEMBAHASAN}

Hasil penelitian kuasi eksperimen yang telah dilaksanakan di SDN Sri Asih didapat berdasarkan data yang diperoleh oleh peneliti melalui proses pengumpulan data serta analisis data dengan menguji normalitas, homogenitas dan uji hipotesis nilai praktik kecerdasan kinestetik siswa sekolah dasar. Hasil uji normalitas nilai praktik kecerdasan kinestetik siswa sekolah dasar dapat pada tabel 1 berikut ini.

\section{Tabel 1. Tests of Normality}

\begin{tabular}{cccc}
\hline & \multicolumn{3}{c}{ Kolmogorov-Smirnova } \\
& Statictic & Df & Sig \\
\cline { 2 - 4 } Nilai Tes Praktek & .158 & 14 & .200 \\
\hline
\end{tabular}

Pada hasil tes praktik diperoleh nilai statistik sebesar 0,158 dan nilai P-value yang diperoleh sebesar 0,200. Karena nilai P-value $>\alpha$, maka $\mathrm{H}_{0}$ diterima (tidak cukup bukti/data 
untuk menolak $\mathrm{H}_{0}$ ). Dengan demikian artinya bahwa pada taraf kepercayaan 95\% data pengetahuan awal gerak pencak silat siswa kelas III SDN Sri Asih berdistribusi normal.

Uji normalitas yang menunjukkan bahwa data berdistribusi normal dilanjutkan dengan pengujian homogenitas. Adapun hasil uji homogenitas nilai praktik kecerdasan kinestetik siswa sekolah dasar yaitu sebagai berikut:

Tabel 2. Test of Homogeneity of Variances

\begin{tabular}{|c|c|c|c|}
\hline Levene Statistic & df1 & df2 & Sig. \\
\hline 14.470 & 1 & 26 & .070 \\
\hline
\end{tabular}

Pada tabel di atas diperoleh nilai P-value sebesar 0,070. Nilai tersebut lebih besar dari pada nilai $\alpha$ yang dipilih yaitu 0,05 . Karena nilai $\mathrm{P}$-value $>\alpha$, maka $\mathrm{H}_{0}$ diterima. Dengan demikian artinya bahwa pada taraf kepercayaan $95 \%$, data pengetahuan awal gerak pencak silat siswa kelas III SDN Sri Asih bersifat homogen.

Untuk mengetahui pengaruh metode drill pencak silat terhadap kemampuan atau kecerdasan kinestetik siswa kelas III SDN Sri Asih, maka dilakukan uji hipotesis dengan hasil sebagai berikut:

Tabel 3. One-Sample Statistics

\begin{tabular}{ccccc}
\hline & N & Mean & Std. Deviation & Std. Error Mean \\
\hline Nilai Praktik & 14 & 45.679 & 40.0778 & 7.5740 \\
\hline
\end{tabular}

Tabel 4. One-Sample Test

\begin{tabular}{cccc} 
& \multicolumn{3}{c}{ Tes Value $=50$} \\
\hline & $\mathrm{T}$ & $\mathrm{df}$ & Sig. (2-tailed) \\
\hline Nilai Praktik & -504.027 & 27 & 120 \\
\hline
\end{tabular}

Pada output bagian pertama menunjukkan bahwa banyaknya data yang diperoleh dari 14 siswa dengan rata-rata sebesar 74,04, simpangan bakunya sebesar 40,0778 dan standar error sebesar 7,5740. Sementara itu untuk output yang kedua menunjukan hasil uji t untuk tes value $=50$ maka nilai thitung $=-504,027$ dan nilai sig 2-tailed $=0,120$. Nilai sig 2-tailed $=120$ dikali oleh $\frac{1}{2}$ dan didapat nilai P-value $=\frac{1}{2} \times 0,120=0,060$. Karena nilai P-value $>\frac{1}{2} \alpha, \mathrm{maka}_{0}$ diterima. Dengan demikian dapat diartikan bahwa metode drill pencak silat yang diajarkan 
pada siswa kelas III SD Negeri Sri Asih berpengaruh secara signifikan terhadap kecerdasan kinestetik siswa kelas III SD Negeri Sri Asih Kabupaten Subang.

Sementara itu, berdasarkan hasil obeservasi menunjukkan bahwa 10 dari 14 orang yang diamati telah memenuhi indikator kecerdasan kinestetik yaitu kemampuan koordinasi dalam melakukan aktifitas fisik, keseimbangan gerak anggota tubuh, keterampilan-keterampilan kinestetik, kekuatan ketahanan tubuh, kelenturan tubuh, dan kecepatan serta kemampuan menerima rangsangan (proprioceptive) dan beberapa hal yang berhubungan dengan sentuhan (tactile dan haptic) dalam pembelajaran pencak silat, sangat suka belajar dengan terlibat secara langsung dalam pembelajaran pencak silat, dan menyukai pengalaman belajar yang nyata dalam pembelajaran pencak silat. Sementara itu 2 orang siswa tidak memenuhi indikator kecerdasan kinestetik yaitu kemampuan koordinasi dalam melakukan aktifitas fisik, keseimbangan gerak anggota tubuh, keterampilan-keterampilan kinestetik, kekuatan ketahanan tubuh, kelenturan tubuh, dan kecepatan serta kemampuan menerima rangsangan (proprioceptive) dan beberapa hal yang berhubungan dengan sentuhan (tactile dan haptic) pembelajaran pencak silat. Satu orang siswa tidak memenuhi indikator kecerdasan kinestetik yang sangat suka belajar dengan terlibat secara langsung dalam pembelajaran pencak silat. Serta terdapat satu orang siswa tidak memenuhi indikator kecerdasan kinestetik yang menyukai pengalaman belajar yang nyata dalam pembelajaran pencak silat. Dari sana dapat disimpulkan bahwa siswa kelas III SDN Sri Asih memiliki kecerdasan kinestetik yang baik setelah dipancing oleh pemebelajaran pencak silat.

Dari data hasil penelitian yang diperoleh, uji normalitas pada hasil tes praktik diperoleh nilai statistik sebesar 0,158 dan nilai P-value yang diperoleh sebesar 0,200. Karena nilai P-value $>\alpha$, maka $\mathrm{H}_{0}$ diterima. Itu artinya dengan demikian data tersebut menunjukan bahwa bahwa pada taraf kepercayaan 95\% data pengetahuan awal gerak pencak silat siswa kelas III SDN Sri Asih berdistribusi normal. Sementara untuk tingkat homogen diperoleh data taraf kepercayaan 95\% terdapat perbedaan yang signifikan pada data pengetahuan awal gerak pencak silat siswa. Hal ini dapat dilihat dari nilai P-value sebesar 0,070. Nilai tersebut lebih besar dari pada nilai $\alpha$ yang dipilih yaitu 0,05 . Karena nilai $\mathrm{P}$-value $>\alpha$, maka $\mathrm{H}_{0}$ diterima.

Untuk uji hipotesis dapat disimpulkan bahwa setelah dilaksanakannya perlakuan metode drill pencak silat pada siswa kelas III SD Negeri Sri Asih terdapat pengaruh yang signifikan terhadap kecerdasan kinestetik siswa sekolah dasar. Hal tersebut dapat dilihat dari data hasil perolehan pada output bagian pertama menunjukan bahwa banyaknya data yaitu 14 buah dengan rata-rata sebesar 74,04, simpangan bakunya sebesar 40,0778 dan standar error sebesar 7,5740. Sementara itu untuk output yang kedua menunjukan hasil uji t untuk tes value $=50$ maka nilai thitung $=-504,027$ dan nilai sig 2 -tailed $=0,120$. Nilai sig 2 -tailed $=120$ dikali oleh $\frac{1}{2}$ dan didapat nilai P-value $=\frac{1}{2} \times 0,120=0,060$. Karena nilai $\mathrm{P}$-value $>\frac{1}{2} \alpha$, maka $\mathrm{H}_{0}$ diterima. 
Untuk ketercapaian indikator lain yang menunjukan adanya pengaruh pencak silat terhadap kecerdasan kinestetik siswa SD Negeri Sri Asih yang signfikan terlihat juga dari hasil observasi, di mana hasil tersebut menunjukan bahwa 10 dari 14 orang yang diamati menunjukan bahwa dirinya telah memenuhi indikator kecerdasan kinestetik yaitu kemampuan koordinasi dalam melakukan aktifitas fisik, keseimbangan gerak anggota tubuh, keterampilanketerampilan kinestetik, kekuatan ketahanan tubuh, kelenturan tubuh, dan kecepatan serta kemampuan menerima rangsangan (proprioceptive) dan beberapa hal yang berhubungan dengan sentuhan (tactile dan haptic) pembelajaran pencak silat, sangat suka belajar dengan terlibat secara langsung dalam pembelajaran pencak silat, dan menyukai pengalaman belajar yang nyata dalam pembelajaran pencak silat. Sementara itu 2 orang siswa tidak memenuhi indikator kecerdasan kinestetik yaitu kemampuan koordinasi dalam melakukan aktifitas fisik, keseimbangan gerak anggota tubuh, keterampilan-keterampilan kinestetik, kekuatan ketahanan tubuh, kelenturan tubuh, dan kecepatan serta kemampuan menerima rangsangan (proprioceptive) dan beberapa hal yang berhubungan dengan sentuhan (tactile dan haptic) pembelajaran pencak silat. Satu orang siswa tidak memenuhi indikator kecerdasan kinestetik yang sangat suka belajar dengan terlibat secara langsung dalam pembelajaran pencak silat. Serta satu orang siswa tidak memenuhi indikator kecerdasan kinestetik yang menyukai pengalaman belajar yang nyata dalam pembelajaran pencak silat.

Hasil penelitian ini sejalan dengan pendapat Sonawat \& Gogri (Anggraini, 2017: 66) yang mengungkapkan bahwa kecerdasan kinestetik merupakan kemampuan untuk mengoperasikan seluruh anggota tubuh yang dimiliki untuk mengekspresikan ide, perasaan, dan karya. Kecerdasan ini mencakup keterampilan khusus seperti kemampuan koordinasi dalam melakukan aktifitas fisik, keseimbangan gerak anggota tubuh, keterampilanketerampilan kinestetik, kekuatan ketahanan tubuh, kelenturan tubuh, dan kecepatan serta kemampuan menerima rangsangan (proprioceptive) dan beberapa hal yang berhubungan dengan sentuhan (tactile dan haptic). Kecerdasan ini juga meliputi keterampilan untuk mengontrol gerakan-gerakan tubuh dan kemampuan untuk memanipulasi objek. Sehinggan dengan menggunakan metode drill pencak silat, siswa dapat mengembangkan kecerdasan kinestetik siswa melaui gerakan-gerakan motorik pencak silat yang dibelajarkan kepada siswa sekolah dasar.

Hasil penelitian yang menunjukkan terdapat pengaruh metode drill pencak silat terhadap kecerdasan kinestetik ini juga sejalan dengan penelitian-penelitian terdahulu yang relevan dengan penelitian ini, seperti penelitian yang dilakukan oleh Eva Aulia pada tahun 2016 yang menghasilkan bahwa terdapat pengaruh yang signifikan dari perlakukan senam pencak silat terhadap kecerdasan kinestetik siswa kelompok B TK Aisyiyah Bustanul Athfal tahun ajaran 2015-2016. Hasil tersebut ditunjukkan dari kondisi sebelum dilaksanakannnya perlakuan menggunakan senam pencak silat yaitu sebanyak 22 siswa dengan 62,9\% mulai berkembang, serta sebanyak 13 dengan presentasi 37,1\% berkembang sesuai harapan. Kemudian setelah 
dilakukannya perlakuan dengan menggunakan senam pencak silat, siswa yang masih dalam tahap mulai berkembang tinggal satu orang siswa saja $(29 \%)$, siswa yang lainnya mulai berkembang sesuai harapan hingga mencapai $80 \%$, serta siswa yang tadinya berkembang sesuai harapan kini enam lainnya dengan presentasi 17,1\% berkembang dengan sangat pesat.

Penelitian mengenai kecerdasan kinestetik semakin berkembang di dunia pendidikan, hal tersebut tentunya untuk memajukan kualitas pendidikan, serta mengembangkan berbagai potensi yang dimiliki siswa. Salah satu potensi yang dapat dikembangkan yaitu kecerdasan kinestetik siswa. Berdasarkan hasil penelitian ini, kecerdasan kinestetik siswa dapat berkembang manakala dilakukan melalui kegiatan aktivitas fisik seperti gerak motorik, baik motorik kasar maupun motorik halus. Hasil penelitian ini sejalan pula dengan hasil penelitian yang sudah dilaksanakan Restu Yuningsih pada tahun 2015, dimana telah ditemukan terjadi peningkatan kecerdasan kinestetik siswa dengan melakukan pembelajaran gerak dasar tari Minang. Hasil penelitian tindakan kelompok B1 di Tk Negeri 01 Sungai Pagu Kabupaten Solok Selatan ini ditunjukkan terjadinya peningkatan kecerdasan kinestetik siswa dari hasil persentase rata-rata pra siklus yang awal mulanya hanya menunjukkan sebesar 48,07\%, kemudian setelah dilakukannya tindakan pada siklus Ihasil persentase rata-rata kecerdasan kinestetik siswa naik menjadi 63,54\%. Serta pada siklus II meningkat sesuai target yaitu menjadi 85,12\%. Selain itu, peningkatan kecerdasan kinestetik juga dapat dilihat dari skor item maupun skor hasil kecerdasan kinestetik setiap anak.

Kecerdasan kinestetik siswa yang dapat ditingkatkan melalui aktivitas fisik gerakan juga dapat dilakukan dalam mata pelajaran apapun. Apalagi kegiatan yang mengandung unsur seni dan olaharaga, seperti pecak silat. Pencak silat ini merupakan hasil budaya Indonesia yang mengandung unsur seni dan olahraga. Oleh karena itu, berdasarkan hasil penelitian ini, metode drill pencak silat berpengaruh terhadap kecerdasan kinestetik siswa sekolah dasar. Candra dan Sudarso juga melaksanakan penelitian pada tahun 2014 yang menerapkan metode drill pada pembelajaran permainan bola basket. Penelitiannya menghasilkan bahwa pembelajaran dengan menggunakan metode drill and pracctice memberikan dampak yang lebih baik terhadap hasil belajar chest pass dalam permainan bola basket yaitu sebesar $44.45 \%$. Sehingga metode drill ini sangatlah cocok manakala dibelajarkan pada pendidikan jasmani dan olahraga untuk mengembangkan kecerdasan kinestetik siswa, termasuk pada pembelajaran pencak silat di sekolah dasar.

Penelitian-penelitian tersebut sangat sejalan dan mendukung hasil penelitian ini yang menunjukkan bahwa terdapat pengaruh metode drill pencak silat terhadap kecerdasan kinestetik siswa sekolah dasar. Metode drill ini memang efektif dalam mempengaruhi kecerdasan kinestetik siswa, hal ini dikarenakan pada hakikatnya tujuan dari metode drill yaitu supaya siswa memiliki keterampilan-keterampilan motorik gerak (baik motorik halus, maupun motorik kasar), kemudian supaya dapat mengembangkan kecakapan berfikir siswa, 
serta mengasah kemampuan menghubungkan sebab-akibat yang siswa miliki (Roestiyah 2001: 125). Hal ini tentu mendukung kebermanfaatan metode drill yang mengembangkan keterampilan motorik gerak siswa sehingga kecerdasan kinestetik siswa dapat berkembang dengan baik pula.

Selain itu, Riadi (2013) juga yang menguraikan keunggulan metode drill yang menjadi landasan pengaruh metode drill pencak silat terhadap kecerdasan kinestetik siswa. Kelebihan atau keunggulan dari metode drill tersebut yaitu sebagai berikut: (1) Penugasan dan keterampulan yang diharapkan melalui metode drill relatif dapat ditempuh dengan singat, hail ini dikarenakan melalui metode drill, maka intensitas latihan yang cukup baik, serta pengulangan-pengulangan yang dilakukan membuat siswa dapat mengasai berbagai kemampuan dan keterampilan yang diajarkan, (2) Kebiasaan-kebiasaan belajar secara rutin dan disiplin akan tertanam dengan baik dalam pribadi siswa. Tentunya pernyataan mengenai keunggulan atau kelebihan dari metode drill terhadap pengembangan keterampilan siswa dapat menjadi penguat dalam pengembangan kecerdasan kinestetik, karena kecerdasan kinestetik siswa ini merupakan ketrampilan siswa dalam gerak motorik, sehingga sangat efektif manakala dibelajarkan dengan menggunakan metode drill.

Keefektifan penerapan metode drill pencak silat terhadap kecerdasan kinestetik ini tentu sangatah diperhatikan oleh peneliti dengan cara mengontrol penuh perlakuan dalam menerapkan metode drill dalam pembelajaran pencak silat di sekolah dasar. Penerapan metode drill diadopsi dari langkah-langkah pelaksanaan dalam metode drill yang dikemukakan oleh Djamarah dan Zain (2010: 89), yaitu: (1) Tahap pemberian latihan, tahap ini dilaksanaka sebelum Latihan dimulai, aktivitasnya berupa penyampaian tujuan pembelajaran, pemaparan tugas yang diberikan, kemampuan siswa yang diharapkan, serta waktu yang diberikan dalam menyelesaian latihan, (2) Tahap pelaksanaan latihan, tahap ini dilaksanakan dengan motivasi yang diberikan oleh guru supaya siswa mampu melakukan Latihan secara mandiri, tidak mengandalkan orang lain, serta selalu mengingat berbagai hal yang sudah dipelajari pada saat latihan, (3) Tahap mempertanggungjawabkan latihan, tahap ini dilaksanakan melalui kegiatan refleksi dari apa yang telah dipelajari, serta kendala apa saja yang ditemui siswa dalam proses pelaksanaan keterampilan pada saat latihan, hingga siswa harus mampu mendapatkan solusi untuk mengatasi kendala tersebut.

Berdasarkan hasil penelitian dan pembahasan yang mengaitkan hasil penelitian dengan teori dan penelitian yang relevan, maka dapat menunjukkan bahwa metode drill pencak silat berpengaruh secara signifikan terhadap kecerdasan kinestetik siswa kelas III SDN Sri Asih Kabupaten Subang. Selain itu, siswa kelas III SDN Sri Asih memiliki kecerdasan kinestetik yang baik setelah distimulus dengan metode drill dalam pembelajaran pencak silat di sekolah dasar. 


\section{SIMPULAN DAN SARAN}

Berdasarkan hasil analisis data melalui uji normalitas, uji homogenitas, uji hipotesis, dan pembahasan, maka dapat disimpulkan secara umum bahwa metode drill pencak silat berpengaruh secara signifikan terhadap kecerdasan kinestetik siswa kelas III SDN Sri Asih Kabupaten Subang. Adapun saran yang diperoleh setelah penelitian ini yaitu sebagai berikut:

1. Pengelolaan siswa harus memperhatikan karakteristik siswa, mobilitas siswa dan kemampuan awal siswa yang berbeda-beda

2. Metode drill yang dilaksanakan pada pembelajaran pencak silat untuk mengembangkan kecerdasan kinestetik siswa sekolah dasar sebaiknya dilaksanakan dengan mengkolaborasikan metode lain yang lebih variatif, seperti metode bermain.

3. Sebaiknya dilaksanakan penelitian selanjutnya yang dilakukan dengan metode kualitatif sehingga dapat mendeskripsikan secara detil pelaksanaan metode drill dalam mengembangkan kecerdasan kinestetik siswa sekolah dasar.

\section{DAFTAR PUSTAKA}

Anggraini, Denok Dwi. (2015). "Peningkatan Kecerdasan Kinestetik Melakegiatan Bermain

Sirkuit Dengan Bola (Penelitian Tindakan Di Kelompok A Tk Al Muhajirin Malang Jawa Timur, Tahun 2015) “. E- Jurnal PG-Paud Trunojoyo. 2 (1). 74-75.

Arifin, Zainal. (2016). Evaluasi Pembelajaran. Bandung : PT Remaja Rosdakarya.

Arikunto, Suharsimi. (2008). Penelitian Tindakan Kelas. Jakarta: PT. Bumi Aksara.

Armstrong, Thomas, (2013). Kecerdasan Multiple di Dalam Kelas. Jakarta: PT Indeks.

Aulia, Eva. (2016). Senam Pencak Silat Berpengarub Terbadap Kecerdasan Kinestetik Anak Kelompok

B. Skripsi Universitas Muhammadiyah Surakarta: Tidak diterbitkan.

Cahyaningrum, Khairul. (2015). Upaya Meningkatkan Kecerdasan Kinestetik Melalui Model pembelajaran Aktif Tipe Index Card Match Pada Siswa Kelas Ii Sekolah Dasar Negeri Minomartani 6 Sleman Yogyakarta. Skripsi Universitas Negeri Yogyakarta : Tidak diterbitkan.

Campbell, L., Campbell, B. dan Dickinson, D. (2005). Metode Praktis Pembelajaran Berbasis Multiple Intelligences. Depok: Intuisi Press.

Candra, Basukisna Setya., dan Sudarso. (2014). Penerapan Model Pembelajaran Drill And Practice Terhadap Hasil Belajar Chest Pass Pada Pemainan Bola Basket (Studi Pada Siswa Kelas X SMA Negeri 1 Kota Mojokerto). Jurnal Pendidikan Olahraga dan Kesehatan. Vol. 02 (No. 01) Tahun 2014. Hal. 141 - 145.

Djamarah, Syaiful Bahri., dan Zain, Aswan. (2010). Strategi Belajar Mengajar. Jakarta: Rineka Cipta. 
Gristyutawati Dkk. (2012). "Persepsi Pelajar Terhadap Pencak Silat Sebagai Warisan Budaya Bangsa Sekota Semarang Tahun 2012”. E-Journal Of Physical Education, Sport, Health And Recreation. 1 (3). 129-130.

Indiati, dkk. (2014). Penerapan Metode Latihan (Drill) pada Tari Kreasi untuk Meningkatkan Kecerdasan Kinestetik di Taman Kanak-Kanak Mekar Indah Kota Bengkulu (Penelitian Tindakan Kelas Di Taman Kanak-Kanak Mekar Indah Kota Bengkulu). Tesis Universitas Bengkulu. Tidak diterbitkan.

Lestari dan Yudhanegara. (2015). Penelitian Pendidikan Matematika. Bandung : PT Refika Aditama.

Mulyasari. (2014). Meningkatan Kecerdasan Kinestetikmelaluikegiatan Bermain Air. Jurnal Pendidikan Usia Dini. Vol. 8 (1). 373-382.

Pratama, Toni Yudha. (2017). "Pembelajaran Seni Pencak Silat Terhadap Peningkatan Kebugaran Jasmani Anak Tunagrahita Sedang (Studi Eksperimen Terhadap Siswa Tunagrahita Di Skh X Kota Serang)". E-Jurnal Pendidikan Dan Kajian Seni. 2 (2). 78.

Rasyidin dkk. (2016). Landasan Pendidikan. Bandung : Sub Koordinasi MKDP Landasan Pendidikan UPI.

Riadi, Muchlisin. (2013). Metode Pembelajaran Drill. [Online]. Tersedia: www.kajianpustaka.com/2013/11/metode-pembelajaran-drill.html. $[25$ November 2018]

Roestiyah N. K. (2001). Strategi Belajar Mengajar. Jakarta: Rineka Cipta.

Sudjana, Nana. (2013). Dasar-Dasar Proses Belajar Mengajar. Bandung: Sinar Baru Algensindo.

Sugiyono. (2015). Metode Penelitian Kuantitatif Kualitatif dan R \& D. Bandung: Alfabeta.

Suhaimi, Imam. (2017). "Memberdayakan Kecerdasan Kinestetik Anak Untuk Budaya Literasi Bahasa". E- Jurnal Kredo. 1 (1). 74.

Sukarna. A., Sumarmo., dan Hidayatullah, M. S. (2015). Pedoman Pembelajaran Pencak Silat. Bandung: Ar Raafi.

Undang-undang Sistem Pendidikan Nasional No. 20 Tahun 2003.

Wiganda, Dodong. (2019). Penerapan Metode Bermain dalam Meningkatkan Kecerdasan Kinestetik Siswa pada Pembelajaran Akuatik di Sekolah Dasar. JMIE: Journal of Madrasah Ibtidaiyah Education. 3. (1), 32-40.

Winarsih, Sudarti. (2013). Upaya Meningkatkan Kecerdasan Kinestetik Melalui Bermain Kucing dan Tikus Pada Siswa Kelompok B Di Tk Model Sleman Yogyakarta. Skripsi Universitas Negeri Yogyakarta : Tidak Diterbitkan.

Yarmani dan Sutisyana. (2017). "Analisis Tendangan Sabit Pada Perguruan Pencak Silat Tapak Suci Di Kota Bengkulu “. E-Jurnal Ilmiah Pendidikan Jasmani. 1 (2), 102-103. 
Yungingsih, Restu. (2015). "Peningkatan Kecerdasan Kinestetik Melalui Pembelajaran Gerak Dasar Tari Minang (Penelitian Tindakan Kelompok B1 Di Tk Negeri 01 Sungai Pagu Kabupaten Solok Selatan Tahun 2015) “. E-Jurnal Pendidikan Usia Dini. 9 (2). 235. 